\title{
PERSEPSI PETANI TERHADAP KINERJA PENYULUH DI DESA KLAMPOKAN DALAM PENGEMBANGAN PADI ORGANIK
}

\author{
Darma Catur Saputri ${ }^{1)}$, Sulistyaninsih ${ }^{2 *}$ ) \\ Fakultas Pertanian, Universitas Abdurachman Saleh Situbondo \\ *Email Korespondensi : lis_sulistyaningsih@yahoo.com
}

\begin{abstract}
Abstrak
Kompetensi Penyuluh pertanian perlu mendapat perhatian yang serius, karena peningkatan dan penurunannya akan berpengaruh langsung terhadap peningkatan dan penurunan kinerja penyuluh. Kompetensi yang tinggi akan sangat mendukung kinerja seseorang dalam melaksanakan tugas rutinnya. Tinggi rendahnya tingkat kompetensi akan berpengaruh langsung terhadap sasaran yang dicapai. Keberpihakan penyuluh kepada petani belum tampak. Seperti keterlibatan penyuluh sebagai tenaga (penyuluh) pendamping dalam penyaluran kredit Pengembangan Usaha Agribisnis Pedesaan (PUAP) belum sesuai dengan ketentuan yang berlaku. Penyuluh Pertanian dan Tenaga Harian Lepas Tenaga Bantu Penyuluh Pertnian (THL-TBPP) dalam menyusun rencana pupuk bersubsidi, tidak di dukung data kebutuhan riil petani di lapangan. Penghitungan hanya berdasarkan prediksi penggunaan pupuk per hektar dikalikan total luas arel pertanian di tingkat kecamatan.Tujuan yang hendak dicapai peneliti untuk yaitu: untuk mengetahui persepsi petani terhadap kinerja penyuluh dalam pengembangan padi organik Kelompok Tani Tirto Dimulyo III Desa Klampokan. Berdasarkan hasil penelitian bahwa persepsi petani terhadap kinerja penyuluh dalam pengembangan padi organik Kelompok Tani Tirto Dimulyo III Desa Klampokan termasuk dalam klasifikasi sedang. Faktor-faktor yang berhubungan nyata dengan persepsi petani terhadap kinerja penyuluh dalam pengembangan padi organik yang meliputi tingkat pendidikan, pengetahuan petani, dan interaksi sosial petani, umur dan pengalaman kerja berhubungan nyata dengan persepsi petani terhadap kinerja penyuluh dalam pengembangan padi organik..
\end{abstract}

Kata Kunci : Persepsi Petani, Kinerja Penyuluh

\begin{abstract}
The Competence of Agricultural Instructors needs serious attention, because the increase and decrease directly affect the performance of them. High and low levels of competence will have a direct effect on the objectives achieved. The alignment of instructor to farmers has not yet been seen. The involvement of instructor as assistants in distribution of Rural Agribusiness Development Credit (PUAP) is not yet in accordance with applicable regulations. Agricultural instructor and Daily Workers - instructor Assistants (THL-TBPP) in preparing subsidized product plans, are not supported by data on real needs of farmers in the field. Calculations are only based on predictions of fertilizer use per hectare multiplied by the total area of agriculture at the sub-district level.The aim of the researchers was to find out the perceptions of farmers on the performance of instructor in the organic rice development of TirtoDimolyo III farmer group in Klampokan Village. Based on the results of the study, it was concluded that the perceptions of farmers on the performance of instructor classified in the medium classification. Factors that are significantly related to farmers'perceptions of the performance of instructor arethe level of education, farmers' knowledge, and social interaction of farmers, age and work experience which is significantly related to farmers'perceptions towardthe instructors' performance in developing organic rice.
\end{abstract}

Key Words: Farmer Perception, Agricultural Instructor 


\section{PENDAHULUAN}

Dalam Pasal 1 ayat (2) UU No.16/2006 yang dimasksud dengan penyuluhan adalah proses pembelajaran bagi pelaku utama serta pelaku usaha agar mereka mau dan mampu menolong dan mengorganisasikan dirinya dalam mengakses informasi pasar, teknologi, permodalan, dan sumberdaya lainnya, sebagai upaya meningkatkan produktifitas, efisiensi usaha, pendapatan dan kesejahteraannya, serta meningkatkan kesadaran dalam pelestarian fungsi lingkungan hidup. Pelaku utama kegiatan pertanian, perikanan, dan kehutanan merupakan masyarakat di dalam dan di sekitar kawasan hutan, petani, pekebun, peternak, nelayan, pembudidaya ikan, pengolahan ikan, beserta keluarga intinya.

Penyuluhan semestinya dilakukan dengan menggunakan pendekatan partisipatif melalui mekanisme kerja dan metode yang disesuaikan dengan kebutuhan serta kondisi pelaku utama ddan pelaku usaha. Berdasarkan UU No. 16/2006 tersebut telah dibentuk Peraturan Pemerintah Republik Indonesia Nomor 43 Tahun 2009 (PP No.43/2009) tentang Pembiayaan, Pembinaan, dan Pengawasan Penyuluhan Pertanian, Perikanan, dan Kehutanan. Mengingat berbagai kendala yang dijumpai di lapangan, implementasi dari PP No. 43/2009 ini belum sesuai dengan rencana.

Menurut Mardikanto (2008) telah mengidentifikasi kendala yang dihadapai penyuluh dalam melaksanakan tugasnya yaitu: (1) skala dan kompleksitas dari tugastugas penyuluh; (2) ketergantungan terhadap kebijakan pemerintah; (3) ketidakmampuan aparat pemerintah untuk menelusuri sebab akibat yang ditimbulkan oleh kegiatan penyuluhan, kaitannya dengan masalah-masalah yang dihadapi, dukungan politis, alokasi anggaran dan akuntabilitas kegiatan penyuluhan; (4) dukungan dan komitmen politis yang berubah-ubah, terutama yang diakibatkan oleh seringnya terjadi pergantian (pemegang) kekuasaan di tingkat pusat; (5) akuntabilitas, yang menyangkut kinerja penyuluhan, dan kinerja staf yang berhubungan dengan petani (terutama penyuluh pertanian, peneliti); (6) kelayakan sebagai lembaga layanan inovasi dan informasi yang harus mampu menjangkau semua kelompok sasaran, aparat pemerintah di lapisan bawah, dan pemangku kepentingan lain yang memerlukan; (7) keberlanjutan operasionalisasi fiskal dan sumber daya lain, baik karena ketidakpastian anggaran maupun rendahnya pengembalian dana yang telah digunakan untuk kegiatan penyuluh; serta (8) masih lemahnya interaksi antara penyuluhan dengan penelitian.

Kompetensi Penyuluh pertanian perlu mendapat perhatian yang serius, karena peningkatan dan penurunannya akan berpengaruh langsung terhadap peningkatan dan penurunan kinerja penyuluh. Kompetensi yang tinggi akan sangat mendukung kinerja seseorang dalam melaksanakan tugas rutinnya. Tinggi rendahnya tingkat kompetensi akan berpengaruh langsung terhadap sasaran yang dicapai.

Menurut Herawati, dkk (2014), kembalinya sistem pertanian organik dapat memberi solusi terhadap masalah penurunan produktivitas lahan pertanian di Indonesia. Menurut berbagai praktisi di bidang organic farming, dalam jangka panjang produktivitas lahan pertanian organik lebih tinggi atau setidaknya sama dengan produktivitas lahan pertanian konvensional. Namun, barriers to entry untuk memasuki usaha ini cukup besar, antara lain dalam hal biaya konversi lahan yang memakan waktu sekitar dua tahun, biaya sertifikasi yang cukup mahal serta sistem multikultur dan pencegahan hama yang membuat komponen labor cost menjadi tinggi dibandingkan dengan sistem konvensional.

Persepsi sebagian besar petani terhadap kemampuan penyuluh yang terkait dengan penguasaan penyuluhan mengenai teknik budidaya komoditas pertanian dinilai memadai, termasuk pengetahuan tentang produksi tanaman padi. Penyuluh dinilai mampu menjelaskan inovasi suatu teknologi dan dapat berkomunikasi dengan 
bahasa yang mudah dipahami petani. Penyuluh di Desa Klampokan telah ikut serta membangun kerjasama antara pengurus kelompok tani dan pedagang tingkat kabupaten dalam pemasaran produksi pertanian, sehingga kelompok tani mempunyai posisi tawar yang kuat.

Fakta menunjukkan bahwa kesetaraan penyuluh dan petani belum terwujud dengan baik. Ini ditandai dengan instruksi penyuluh kepada petani, seperti pembuatan kompos dari kotoran domba dan sapi. Hubungan yang terjalin adalah seperti antara guru dan murid. Interaksi antara penyuluh dengan petani belum mencerminkan hubungan yang egaliter. Keberpihakan penyuluh kepada petani belum tampak. Seperti keterlibatan penyuluh sebagai tenaga (penyuluh) pendamping dalam penyaluran kredit Pengembangan Usaha Agribisnis Pedesaan (PUAP) belum sesuai dengan ketentuan yang berlaku. Penyuluh Pertanian dan Tenaga Harian Lepas Tenaga Bantu Penyuluh Pertnian (THL-TBPP) dalam menyusun rencana pupuk bersubsidi, tidak di dukung data kebutuhan riil petani di lapangan. Penghitungan hanya berdasarkan prediksi penggunaan pupuk per hektar dikalikan total luas area pertanian di tingkat kecamatan.

Kebanyakan petani tidak mengenal penyuluhan dan tidak pernah dikunjungi penyuluh menyatakan bahwa penyuluh tidak melakukan kegiatan penyuluhan yang menjadi tugasnya. Tugas penyuluhan pertanisan ataupun THL-TBPP selain membina petani, juga menyusun program, laporan kegiatan per bulan, membuat rencana kebutuhan pupuk bersubsidi, mengikuti pelatihan gabungan di BPP dengan instruktur dari kabupaten dan menghadiri rapat mingguan. Bagi THL-TBPP masih ditambah beban tugas untuk mengikuti kegiatan pembinaan yang di lakukan di kabupaten.

Tjitropranoto (2003) menyoroti kompetensi penyuluh perlu di tingkatkan melalui pemahaman penyuluh terhadap sifat-sifat, potensi dan keadaan sumberdaya alam, iklim serta lingkungan diwilayah petani binaan. Selain itu penyuluh perlu memahami perilaku petani dan potensi pengalamannya, pemahaman terhadap pengembangan usaha pertanian yang menguntungkan petani, membantu petani dalam mengakses informasi harga dan pasar, memahami peraturan perundangan yang berlaku terkait dengan usaha pertanian.

\section{METODE PENELITIAN}

Metode penelitian yang penulis gunakan dalam penelitian ini adalah metode kuantitatif yang diperkuat dengan metode kualitatif deskriptif dengan pendekatan survey. Metode penelitian survey digunakan untuk mendapatkan data dari tempat tertentu yang alamiah (bukan buatan), tetapi peneliti melakukan perlakuan dalam pengumpulan data.

Sampel merupakan bagian dari jumlah dan karakterisitik yang dimiliki oleh suatu populasi yang akan diteliti. Penentuan sampel dalam penelitian ini dilakukan dengan jenis Non Probability Sampling. Non Probability Sampling jenis sampel ini tidak dipilih secara acak. Tidak semua unsur atau elemen populasi mempunyai kesempatan sama untuk bisa dipilih menjadi sampel. Dalam penelitian ini sampel yang akan diambil adalah seluruh anggota anggota kelompok Tani Tirto Dimulyo III Desa Klampokan Kecamatan Panji Kabupaten Situbondo yaitu 15 orang. Metode sampel jenuh adalah teknik penentuan sampel bila semua anggota populasi digunakan menjadi sampel

Metode pengumpulan data yang digunakan dalam penelitian ini adalah sebagai berikut:

a. Kuesioner (Angket)

Menurut Sugiyono, (2016), metode kuesioner merupakan teknik pengumpulan data yang dilakukan dengan cara memberi seperangkat pertanyaan atau pernyataan tertulis kepada responden untuk dijawab. Data yang ingin diperoleh 
peneliti yakni dengan cara memberi angket kepada kelompok Tani Tirto Dimulyo III Desa Klampokan. Agar data yang terkumpul dapat berwujud kuantitatif, maka setiap alternatif jawaban diberikan skor atau nilai.

b. Metode Wawancara

Metode wawancara adalah proses memperoleh keterangan untuk tujuan penelitian dengan cara tanya jawab sambil bertatap muka antara pewawancara dengan responden atau orang yang diwawancara. Peneliti menggunakan Wawancara terstruktur yaitu wawancara yang dilaksanakan secara terancana dengan berpedoman pada daftar pertanyaan yang telah dipersiapkan sebelumnya. Teknik pengumpulan data yang digunakan yaitu dengan panduan kuesioner penelitian. Data diperoleh dengan melakukan wawancara dengan pihak kelompok Tani Tirto Dimulyo III Desa Klampokan Kecamatan Panji Kabupaten Situbondo. untuk mendapatkan informasi yang diinginkan.

c. Dokumentasi

Merupakan metode pengumpulan data dengan cara mencari data mengenai halhal atau variabel yang berupa catatan, transkip, buku, surat kabar, majalah, prasasti, notulen, rapat, agenda, dan sebagainya, Arikunto (2010). Dokumen yang digunakan peneliti disini berupa foto, gambar, serta data-data dari kelompok Tani Tirto Dimulyo III Desa Klampokan untuk memudahkan peneliti untuk memperoleh informasi yang diperlukaan selama proses penelitian berlangsung

\section{Analisis Data}

a. Analisa Regresi Linier Berganda

Analisis ini digunakan untuk mengetahui seberapa besar pengaruh variabel bebas terhadap kinerja penyuluhan dalam pengembangan padi organik papda kelompok Tani Tirto Dimulyo III Desa Klampokan . Menurut Sanusi, (2011) untuk mengetahui pengaruh variabel bebas terhadap variabel terikat digunakan rumus analisis regresi linier berganda sebagai berikut:

$$
\mathrm{Y}=a+\mathrm{b}_{1} \mathrm{X}_{1}+\mathrm{b}_{2} \mathrm{X}_{2}+\mathrm{b}_{3} \mathrm{X}_{3}+\mathrm{b}_{4} \mathrm{X}_{4}+\mathrm{b}_{5} \mathrm{X}_{5}+e
$$

$\begin{array}{ll}\text { Keterangan: } & \\ \mathrm{Y} & \text { : Kinerja penyluhan } \\ \mathrm{X}_{1} & \text { : Umur } \\ \mathrm{X}_{2} & \text { : Tingkat Pendidikan } \\ \mathrm{X}_{3} & \text { : Pengalaman Kerja } \\ \mathrm{X}_{4} & \text { : Pengetahuan Petani } \\ \mathrm{X}_{5} & \text { : Interaksi Sosial Petani } \\ \mathrm{a} & \text { : Konstanta } \\ \mathrm{b}_{1} \mathrm{~b}_{2} \mathrm{~b}_{3} \mathrm{~b}_{4} \mathrm{~b}_{5} & \text { : Koefisien regresi }\end{array}$

\section{b. Uji Parsial (Uji t)}

Uji t digunakan untuk melihat secara parsial bagaimana pengaruh variabel bebas $(\mathrm{X})$ terhadap variabel terikat $(\mathrm{Y})$, guna menguji hipotesis yang telah ditetapkan memiliki pengaruh atau tidak, (Sugiyono, 2013). Uji t dapat juga dilakukan dengan melihat nilai signifikansi t masing-masing variabel pada output hasil regresi menggunakan SPSS dengan significance level 0,05 ( $\alpha=5 \%$ ). Jika nilai signifikansi lebih besar dari $\alpha$ maka hipotesis ditolak (koefisien regresi tidak signifikan), yang berarti secara individual variabel independen tidak mempunyai pengaruh yang signifikan terhadap variabel dependen. Jika nilai signifikansi lebih kecil dari $\alpha$ maka hipotesis diterima (koefisien regresi signifikan), 
berarti secara individual variabel independen mempunyai pengaruh yang signifikan terhadap variabel dependen.

\section{c. Uji Simultan (Uji F)}

Uji $\mathrm{F}$ dilakukan untuk melihat secara serentak atau bersama-sama bagaimana pengaruh variabel $\mathrm{X}$ terhadap variabel Y. Pada uji $\mathrm{F}$ dalam penelitian ini menggunakan bantuan program komputer SPSS 22.0 for Windows

Dasar pengambilan keputusan menurut Sanusi (2011) adalah dengan menggunakan angka probabilitas ialah sebagai berikut:

1) Jika $F_{\text {hitung }} \geq F_{\text {tabel }}$ dan nilai Sig $<0,05$, maka $H_{0}$ ditolak dan $H_{a}$ diterima, artinya secara simultan variabel independen mempunyai pengaruh yang signifikan terhadap variabel dependen.

2) Jika $F_{\text {hitung }}<F_{\text {tabel }}$ dan nilai Sig $>0,05$, maka $H_{0}$ diterima dan $H_{a}$ ditolak, artinya secara simultan variabel independen tidak mempunyai pengaruh yang signifikan terhadap variabel dependen.

\section{d. Koefisien Determinasi}

Koefisien determinasi $\left(\mathrm{R}^{2}\right)$ digunakan untuk mengukur seberapa baik garis regresi sesui dengan data aktualnya (good of fit) koefesien determinasi mengukur prosentase total variasi variabel dependen Y yang dijelaskan oleh variabel independen didalam garis regresi (Widarjono, 2010).

\section{HASIL PENELITIAN DAN PEMBAHASAN}

Pengukuhan persepsi petani dalam hal ini penyuluh telah melakukan kerjasama yang baik dengan petani dalam melaksanakan program penyuluhan dan pelaksanaannya telah dirasakan oleh masyarakat petani memberikan dampak positif terhadap kegiatan sosial ekonomi masyarakat petani. Ini dapat dibuktikan bahwa dari keseluruhan petani yang ada di Kecamatan Panji Kabupaten Situbondo, masyarakat petani bergabung dalam kelompok tani. Kreatif atau inisiatif penyuluh pertanian tergolong tinggi, hal ini dikarenakan penyuluh pertanian bersama-sama dengan petani telah melakukan kerjasama terutama untuk memecahakan permasalahan yang dihadapi petani, dalam hal ini penyuluh menanggapi dan berusaha untuk memberikan arahan kepada petani agar dapat memecahakan permasalahan dengan efisien dan efektif terutama masalah pemeliharaan padi seperti pemupukan dan pengendalian hama dan penyakit tanaman.

Hasil analisis pengaruh antara variabel independen dengan variabel dependen menggunakan analisis uji t dikatahui bahwa mempunyai nilai $t_{\text {hitung }} 2,353$. Sementara itu nilai pada $t_{\text {tabel }}$ distribusi $5 \%$ sebesar 2.262. Kesimpulan yang dapat diambil adalah dengan tingkat signifikansi $0,043<0,05$ sehingga nilai $t_{\text {hitung }}>t_{\text {tabel }}(2,353>2.262)$ maka Umur petani berpengaruh nyata terhadap persepsi petani terhadap kinerja penyuluh dalam pengembangan padi organik di kinerja penyuluh dalam pengembangan padi organik Kelompok Tani Tirto Dimulyo III Desa Klampokan Artinya umur memiliki kontribusi secara langsung terhadap persepsi petani terhadap kinerja penyuluh. Hasil ini sejalan dengan Soekartawi (1988) umur petani mempengaruhi kemampuan kerja fisik dan kematangan psikologisnya. Petani setengah baya cenderung yang paling tinggi adopsi inovasinya, karena kekuatan fisik dan kematangan psikologisnya saling mendukung.

Tingkat pendidikan petani berpengaruh nyata mempunyai nilai $t_{\text {hitung }} 4,019$. Sementara itu nilai pada $t_{\text {tabel }}$ distribusi $5 \%$ sebesar 2.262 . Kesimpulan yang dapat diambil adalah dengan tingkat signifikansi $0,001<0,05$ sehingga nilai $t_{\text {hitung }}<t_{\text {tabel }}(5,019<2.262)$ arti tingkat pendidikan petani memiliki kontribusi secara langsung terhadap persepsi petani terhadap kinerja penyuluh. Hasil ini sejalan dengan penelitian Ardiansyah 
(2014) bahwa tingkat pendidikan berpengaruh nyata dengan persepsi petani. Maknanya adalah semakin tinggi tingkat pendidikan petani maka semakin tinggi pula persepsinya terhadap kinerja penyuluh, karena berubahan pendidikan akan merubah respon penyuluh.

Sedangkan Pengalaman kerja berpengaruh nyata dengan tingkat persepsi petani terhadap kinerja penyuluh dalam pengembangan padi organik di Kelompok Tani Tirto Dimulyo III Desa Klampokan Diperoleh hasil nilai $t_{\text {hitung }}$ 3,787. Sementara itu nilai pada $t_{\text {tabel }}$ distribusi 5\% sebesar 2.262. Kesimpulan yang dapat diambil adalah dengan tingkat signifikansi $0,004<0,05$ sehingga nilai $t_{\text {hitung }}>t_{\text {tabel }}(3,787>2.262)$ yang memiliki arti pengalaman kerja petani memiliki kontribusi secara langsung terhadap persepsi petani terhadap kinerja penyuluh. Maknanya adalah semakin lama pengalaman mengenai padi organik maka semakin baik pula persepsi petani terhadap kinerja penyuluh. Pengalaman yang lebih banyak akan meningkatkan pemahaman dan akan akan meningkatkan kesadaran petani mengenai pentingnya pertanian organik.

Pengetahuan petani berpengaruh nyata dengan tingkat persepsi petani terhadap kinerja penyuluh dalam pengembangan padi organik di Kelompok Tani Tirto Dimulyo III Desa Klampokan. Diperoleh hasil thitung sebesar 22,733 lebih besar dibanding $t_{\text {tabel }}$ sebesar 2,262 sehingga berpengaruh nyata dengan persepsi petani terhadap kinerja penyuluh dalam pengembangan padi organik dengan tingkat kepercayaan yang memiliki arti pengetahuan petani memiliki kontribusi secara langsung terhadap persepsi petani terhadap kinerja penyuluh. Maknanya adalah semakin tinggi pengetahuan petani mengenai padi organik maka semakin baik pula persepsi petani terhadap kinerja penyuluh. Menurut Utami (2008) dalam pengembangan beras organik diperlukan pendampingan yang cukup oleh PPL agar pengetahuan yang didapat petani lebih banyak lagi sehingga petani mampu menerapkan usahatani padi organik dengan baik.

Interaksi sosial petani berpengaruh nyata dengan tingkat persepsi petani terhadap kinerja penyuluh dalam pengembangan padi organik di Kelompok Tani Tirto Dimulyo III Desa Klampokan. Hasil ini sejalan dengan penelitian Ardiansyah (2014) dan Kusnani (2013), bahwa interaksi sosial berpengaruh nyata dengan persepsi petani. Diperoleh nilai thitung sebesar 4,130 lebih besar dibanding dengan nilai tabel sebesar 2,262 sehingga berpengaruh nyata dengan persepsi petani terhadap kinerja penyuluh dalam pengembangan padi organik yang memiliki arti interaksi sosial petani memiliki kontribusi secara langsung terhadap persepsi petani terhadap kinerja penyuluh. Maknanya adalah semakin sering petani berinteraksi dengan petani, kelompok tani dan penyuluh maka akan semakin tinggi persepsi seseorang terhadap suatu objek atau kinerja penyuluh.

Persepsi petani terhadap kinerja penyuluh pertanian di Kecamatan Panji Kabupaten Situbondo pada faktor umur, tingkat pendidikan, pengalaman kerja, pengetahuan petani, dan interaksi sosial petani, termasuk dalam kategori tinggi, hal ini dikarenakan penyuluh telah melaksanakan tugas dan tanggungjawabnya sebagai penyuluh untuk memberikan penyuluhan kepada petani dalam upaya memecahkan permasalahan yang dihadapi petani. Sebagaimana yang diketahui bahwa fungsi utamanya yaitu mengubah perilaku petani melalui pendidikan non formal sehingga petani mempunyai kehidupan yang lebih baik secara berkelanjutan. Berdasarkan hasil penelitian Sapar et al (2012) penyuluh yang berhasil adalah penyuluh yang dapat merancang dan melaksanakan suatu program pembelajaran, dimana materi dan metodenya sesuai dengan kondisi dan karakteristik petani.

Ketertarikan petani sampai saat ini masih mau menanam padi organik karena menurut mereka padi organik harga jualnya lebih tinggi dibandingkan dengan anorganik. Selain itu, padi organik ke depannya memiliki prospek yang sangat baik. 
Pada awal implementasi padi organik produksinya lebih rendah dibandingkan padi anorganik. Namun, semakin lama produksi padi organik lebih tinggi.

\section{KESIMPULAN}

Berdasarkan dari hasil penelitian yang telah dilakukan dan telah diuraikan sebelumnya, maka dapat ditarik kesimpulan dari keseluruhan hasil penelitian yaitu persepsi petani terhadap kinerja penyuluh dalam pengembangan padi organik Kelompok Tani Tirto Dimulyo III Desa Klampokan termasuk dalam klasifikasi tinngi. Faktor-faktor persepsi petani terhadap kinerja penyuluh dalam pengembangan padi organik yang meliputi umur, tingkat pendidikan, pengalaman kerja, pengetahuan petani, dan interaksi sosial petani, berpengaruh nyata dengan persepsi petani terhadap kinerja penyuluh dalam pengembangan padi organik.

\section{REFERENSI}

Adiwilaga, Anwas. 2000. Ilmu Usaha Tani: Cetakan II. Bandung: Alumni

Andoko, A ., 2002. Budidaya Padi Secara Organik. Cetakan-I. Penebar Swadaya, Jakarta. BALITPANG, 1989. Padi. Edisi ke-2. Pusat Penelitian dan Pengembangan Tanaman Pangan. Bogor.

Arikunto, S. 2010. Prosedur penelitian: Suatu Pendekatan Praktik. (Edisi Revisi). Jakarta : Rineka Cipta.

Arimbawa, P. 2007. Penerapan Kelompok untuk Meningkatkan Kemampuan Anggota dalam Penerapan Inovasi Teknologi.Institut Pertanian Bogor. Bogor.

As'ad S. U, Moh. 2002. Psikologi Industri : Seri Ilmu Sumber Daya Manusia. Edisi keempat. Yogyakarta: Liberty.

Bimo Walgito. 2004. Pengantar psikologi Umum. Jakarta: Penerbit Andi.

Chaplin, J.P. 2006. Kamus Lengkap Psikologi. Jakarta: PT. RajaGrafindo Persada.

Departemen Pertanian, 2006, Pedoman Pengolahan Limbah Industri Kelapa Sawit, Direktorat Pengolahan Hasil Pertanian, Jakarta

Departemen Pertanian. 2008. Kebijakan Teknis Program Ketahanan Pangan. Jakarta : Departemen Pertanian.

Dessler, Gary. 2007. Manajemen Sumber Daya Manusia. Edisi Kesepuluh, Jilid 2, PT. Indeks: Jakarta.

Ghozali, Imam. 2011. Aplikasi Analisis Multivariate Dengan Program SPSS. Edisi Ketiga. Semarang: Badan Penerbit Universitas Diponegoro.

Gomes, Faustino Cardoso. 2000. Manajemen Sumber Daya Manusia, Cetakan Keempat. Yogyakarta. Penerbit Andi.

Handoko, T. Hani. 2002. Manajemen Personalia dan Sumber Daya Manusia. Yogyakarta : BPFE.

Hariandja, M. T. E.. 2007. Manajemen Sumber Daya Manusia. Ghalia. Indonesia. Jakarta.

Hawkins dan Van den Ban. 2002. Penyuluhan Pertanian. Kanisius. Yogyakarta.

Herawati, Noknik Karliya dkk. 2014. Viabilitas Pertanian Organik Dibandingkan dengan Pertanian Konvensional. Parahyangan: LPPM UKP.

Mardikanto. 2008. Sistem Penyuluhan Pertanian. Sebelas Maret University Press. Surakarta.

Mayrowani, H., Supriyati, T. Sugino. 2010. Analisa Usahatani Padi Organik di Kabupaten Sragen. Laporan Penelitian. JIRCAS.

Nasution. 2001. Manajemen Mutu Terpadu (Total Quality Management), Anggota IKPI, Ghalia Indonesia: Jakarta.

Robbins, Stephen P. 2006. Perilaku Organisasi. Edisi kesepuluh. Jakarta: PT Indeks Kelompok Gramedia 
Sadikin M., 2001, Pengembangan Sektor Pertanian (Penanganan Komoditi Unggul), UGM Press, Jakarta.

Sanusi, Anwar. 2011. Metodologi Penelitian Bisnis. Jakarta: Salemba Empat.

Saptana, Supena, dan Bastuti,T. P. 2002. Efisiensi dan Daya Saing Usahatani Tebu dan Tembakau di Jawa Timur dan Jawa Tengah. Pusat penelitian dan Pengembangan sosial Ekonomi Pertanian.

Sarwono, Sarlito Wirawan. 1996. Pengantar Umum Psikologi. Jakarta: Bulan Bintang.

Sinambela, Litjan Poltak, dkk. 2009. Reformasi Pelayanan Publik: Teori, Kebijakan, dan Implementasi. Jakarta: PT Bumi Aksara.

Slamet, 2000, Agrikultur, LPN-IPB-Bogor.

Sobur, Alex. 2003. Psikologi Umum. Bandung: Pustaka Setia.

Sugiyono, 2013, Metode Penelitian Kuantitatif, Kualitatif dan R\&D, Bandung : Alfabeta.

Suhardiyono, 2001. Penyuluhan, Petunjuk bagi penyuluh pertanian, Erlangga, Jakarta.

Tjitropranoto, P., 2003, Penyuluh Pertanian Masa Kini dan Masa Depan. Dalam Ida Yustina dan Adjat Sudradjat. Membentuk Pola Perilaku Manusia Pembangunan, Bogor: IPB Press

Undang-Undang No 16 Tahun 2006 tentang Sistem Penyuluhan Pertanian, Perikanan, dan Kehutanan. Jakarta

Walgito, Bimo. 2002. Pengantar Psikologi Umum. Yogyakarta: Andi Offset.

Winardi. 2002. Motivasi dan Pemotivasian dalam Manajemen. Jakarta: Raja Grafindo Persada 